\title{
LA CAPILLA REAL DE LA SANTA CRUZ EN LA CATEDRAL DE TOLEDO. RELIQUIAS, EVOCACIONES, USO Y DECORACIÓN*
}

\author{
THE ROYAL CHAPEL OF THE HOLY CROSS IN TOLEDO \\ CATHEDRAL. RELICS, EVOCATIONS, USE AND DECORATION
}

\author{
MATILDE MiQuel JUAN \\ Universidad Complutense de Madrid \\ http://orcid.org/0000-0003-3145-3216
}

\begin{abstract}
Resumen: A través de este artículo se pretende examinar la funcionalidad y significado de la capilla de la Santa Cruz de la Catedral de Toledo. En el análisis de la capilla de exequias toledana se evocaba el templo del Santo Sepulcro, al recordar los nombres dados a esta capilla: la capilla de la Santa Cruz y la subterránea del Santo Sepulcro. Este estudio procura analizar la evolución cultual y formal de la cabecera de la catedral de Toledo primero dentro del ideario del arzobispo Jiménez de Rada, y después como capilla funeraria y de reliquias de la Santa Cruz, contemplando su estructura y decoración.
\end{abstract}

Palabras clave: catedral de Santa María de Toledo; Rodrigo Jiménez de Rada; espacio regio funerario; capilla mayor; Sancho IV.

\begin{abstract}
This article seeks to determine the functional nature and significance of the chapel of the Holy Cross in Toledo Cathedral. The Temple of the Holy Sepulchre was evoked in the analysis of the Toledo funeral chapel when recalling the names given to this chapel: the chapel of the Holy Cross and the underground chapel of the Holy Sepulchre. This study aims to analyze the cultural and formal evolution of the East end of Toledo Cathedral, first within the ideology of Archbishop Jiménez de Rada, and later as the funerary and reliquary Chapel of the Holy Cross, by examining its structure and decoration.
\end{abstract}

Keywords: cathedral of Santa María de Toledo; Rodrigo Jiménez de Rada; royal burial place; main chapel; Sancho IV.

\section{SUMARIO}

1. Introducción.--; 2. Un proyecto político: Rodrigo Jiménez de Rada y la monarquía castellana.- 3. La cabecera de Rodrigo Jiménez de Rada. De mezquita a catedral.4. Sancho IV y su enterramiento en la dives toletana.- 5. Estructuras diáfanas y advocaciones simbólicas.- 6. La ornamentación: entre apóstoles y reliquias.- 7. Conclusiones.- 8. Bibliografía citada.

\footnotetext{
* Artículo realizado dentro del proyecto HAR2012-32720: La formación del pintor y la práctica de la pintura en los reinos hispanos (1350-1500), concedido por el Ministerio de Economía y Competitividad.
} 


\section{INTRODUCCIÓN ${ }^{1}$}

Las evocaciones del templo de Salomón o del Santo Sepulcro como edificios singulares de la historia de la Iglesia formaban parte del imaginario colectivo medieval, y su representación suponía un acercamiento consciente a la divinidad y su santidad. La sublimación de estos simbólicos templos se produjo tempranamente en toda Europa de diferentes formas y en grados muy distintos de asimilación. La copia o imitación de una obra de arte, o de un templo específicamente, podía realizarse a través de su forma, proporción, medida, denominación, estructura, o incluso decoración. Desde el seminal artículo de Richard Krautheimer hasta artículos más recientes se observa la amplia capacidad medieval de evocar un edificio, una obra o un inclusive un ritual de la historia sagrada ${ }^{2}$. Esta puesta al día de los medios y formas de rememorar ha hecho que los historiadores nos planteemos con plenitud determinadas asociaciones simbólicas y a la postre la comprensión de una obra de arte en todas sus facetas.

A través de este artículo se pretende dar una vuelta de tuerca más a la propuesta funcionalidad y significado de la capilla de la Santa Cruz de la catedral de Toledo, al analizar la evolución cultual y formal de la cabecera de la catedral de Toledo primero dentro del ideario del arzobispo Jiménez de Rada, y después como capilla funeraria y de reliquias de la Santa Cruz, contemplando su estructura, decoración pictórica y escultórica como una asimilación medieval del templo del Santo Sepulcro de Jerusalén al conmemorar la crucifixión, el Santo Entierro y la inventio de la Santa Cruz ${ }^{3}$. Las transformaciones de la cabecera a finales del s. XV y principios del XVI desvirtuaron este programa ideológico, perdiendo así su estructura original y su carácter regio.

\footnotetext{
${ }^{1}$ Quiero agradecer a mis compañeros del grupo de investigación y departamento de Historia del Arte I las ideas propuestas, y muy especialmente a los profesores Olga Pérez Monzón, Pilar Martínez Taboada, Javier Martínez de Aguirre, Juan Carlos Ruiz Souza y Diego Suárez Quevedo. Igualmente debo citar la inestimable ayuda de D. Juan Sánchez Rodríguez, deán de la Catedral Primada de Toledo.

${ }^{2}$ Krautheimer 1942, pp. 1-33. En esta línea Ramírez 1990, pp. 131-150; Ramírez 1991, pp. 43-100; Coldstream 2002, pp. 149-173; Carpo 2003, pp. 67-75; Martínez de Aguirre, Gil 2004; Carrero 2010, pp. 321-334; Martínez de Aguirre 2012, pp. 217-242.

${ }^{3}$ Algunas de las principales citas: Conant 1956, pp. 1-48; Coüasnon 1974; Corbo 19811982; Folda 1995, pp. 175 y ss.; Kroesen 2000; Ousterhout 2003, pp. 4-23.
} 


\section{UN PROYECTO POLÍTICO: RODRIGO JIMÉNEZ DE RADA Y LA MONARQUÍA CASTELLANA}

Rodrigo Jiménez de Rada ${ }^{4}$ fue un eclesiástico formado en Bolonia y en París, representaba a la alta jerarquía eclesiástica de la Iglesia y a la vez al grupo de consejeros y hombres de confianza de la monarquía castellana. Concretamente fue consejero y diplomático del rey de Navarra Sancho VII y de los castellanos Alfonso VIII y Fernando III, además de canciller de este último monarca. Su llegada al arzobispado de Toledo se produjo en 1209, y sus constantes fueron claras y precisas: mantener y reafirmar la dignidad instituida de la catedral primada de España, erigirse en el pilar de la fe cristiana en la Península y actuar al servicio de la Iglesia católica y la monarquía castellana. Para ello fue el promotor de la cruzada cristiana contra los almohades de al-Andalus, llegó incluso a participar en la batalla de las Navas de Tolosa, ganando numerosos señoríos, inició la construcción de una nueva catedral gótica como emblema del cristianismo y, por último, no solo actuó como consejero de reyes, sino que, como parte de una política de exaltación de la primada, dispuso un espacio catedralicio al servicio de la monarquía como insigne lugar de enterramiento regio ${ }^{5}$.

Jiménez de Rada fue uno de los grandes promotores artísticos del s. XIII hispano, y lo que parece más importante, un personaje con una visión y proyección internacional. A su labor como iniciador y promotor de la gran catedral gótica de Toledo se une su papel como traductor, compilador de la crónica castellana De Rebus Hispaniae sive Historia Gothica (también conocida como Historia de los Hechos de España, Historia gótica o Crónica del toledano), y autor de obras históricas y teológicas. Estuvo presente en los concilios de Letrán y Lyon, y sobre todo intentó ponerse al servicio de la monarquía para alcanzar y ensalzar a la propia Iglesia, con una estrategia política similar a la que desarrolló el abad Suger (1081-1151) en la abadía de Saint Denis junto a los reyes Luis VI y VII de Francia. Como bien apunta el doctor Thomas Nickson la construcción de la catedral de Toledo era el complemento a la construcción de la historia de España en su Historia de Rebus Hispaniae, puesto que los dos definían a la iglesia toledana como el epicentro histórico, geográfico y espiritual de España ${ }^{6}$. En un análisis comparativo, la figura de Jiménez de Rada podría confrontarse a la del abad Suger de Saint Denis,

\footnotetext{
${ }^{4}$ Gorosterratzu 1925; Estella 1926; Ballesteros 1935; Linehan 1971; Grassotti 1973; Jiménez de Rada 1989; Gonzálvez 1997, pp. 165-202; Hernández 2003, pp. 15-71; Pick 2006.

${ }^{5}$ Hernández 2003, pp. 15-71.

${ }^{6}$ Ruiz 2009, pp. 237-242; Ruiz 2012-2013, pp. 219- 224; Nickson 2010, p. 148. Recientemente, sobre la catedral de Toledo: Nickson 2015.
} 
hombre de Iglesia, consejero de reyes, pensador político y reformador de la abadía de Saint Denis ${ }^{7}$.

\section{LA CABECERA DE RODRIGO JIMÉNEZ DE RADA. DE MEZQUITA A CATEDRAL}

La transformación de la antigua mezquita mayor de Toledo en catedral gótica fue un proceso largo en el que el arzobispo Jiménez de Rada jugó el papel más significativo (fig. 1). Los comienzos de la nueva catedral, tras la destrucción de algunas de las zonas de la antigua mezquita por el arzobispo Martín López de Pisuerga, se centró en la zona de la cabecera para la que se compró los terrenos anexos y comprenden lo que se ha denominado la primera campaña constructiva datada entre 1221 (colocación de la primera piedra) y 1244 (cuando el pueblo toledano expulsa al Cabildo de la ciudad, y poco antes del fallecimiento de Jiménez de Rada en 1247).
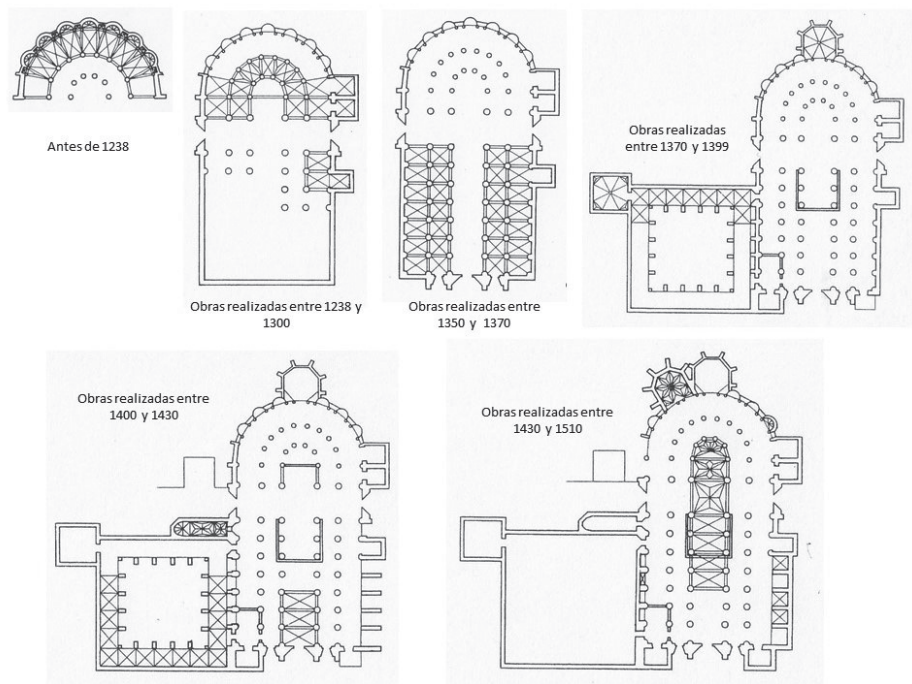

Fig. 1. Catedral primada de Toledo, evolución constructiva, según Pérez 1998.

\footnotetext{
${ }^{7}$ Recientemente: Poirel 2001; Leniaud 2012; Ceccarini 2013.
} 
La capilla mayor de la catedral de Toledo, diseñada desde los mismos inicios constructivos góticos del templo, se caracteriza por una disposición semicircular, rodeada por una doble girola, y erigida tomando en consideración los novedosos diseños de las catedrales de París, Bourges o Le Mans ${ }^{8}$. Las posibles relaciones de Jiménez de Rada con territorios europeos donde se había formado, como el caso de París, la presencia de arquitectos franceses en Castilla y la expansión de las nuevas formas góticas en la Península Ibérica son cuestiones fundamentales que explican las estructuras góticas de la catedral toledana ${ }^{9}$. Desde hace tiempo se estudia como una peculiaridad toledana la estructura centralizada de la cabecera, con unas dimensiones más cortas que las habituales en las catedrales francesas, y que aluden a un espacio de planta centralizada que se habría asociado al templo de Salomón o al mismo Santo Sepulcro $^{10}$.

En 1211 Jiménez de Rada acudía al monasterio de las Huelgas para enterrar al primogénito Fernando, hijo de Alfonso VIII, y pocos años más tarde, en 1215 instituía una capellanía por el alma de Alfonso VIII en la primada ${ }^{11}$. Y fue precisamente en la capilla del Espíritu Santo, existente en el primer tramo previo a las capillas radiales semicirculares de la girola del lado de la epístola, donde se alojaron inicialmente los sepulcros de Alfonso VII el Emperador (1126-1157) y Sancho III el Deseado (1157-1158), durante el arzobispado de Jiménez de Rada. También se la conoce como la Capilla de los Reyes Viejos o de la Virgen del Alcázar. Blas Ortíz nos proporciona una descripción de la capilla del Espíritu Santo tal y como se encontraba en el s. XVI, y aunque algo confusa, resulta de gran interés al informarnos que la capilla tenía originalmente, además de los sepulcros reales, tres altares con tres retablos dedicados al Espíritu Santo Paráclito (centro), san Juan Evangelista (derecha) y san Miguel (izquierda) ${ }^{12}$. Además tenía en la pared meridional un grupo escultórico de la llegada del Espíritu Santo sobre los apóstoles y en el muro norte una imagen de Jesucristo Salvador.

\footnotetext{
${ }^{8}$ Von Konsradsheim 1975, pp. 217-224. Sobre la importancia de estos espacios dentro de los ceremoniales medievales y las reformas posteriores: Castillo 2007, pp. 229-259; Lop 2008, pp. 223-262.

${ }^{9}$ Sobre las transformaciones cultuales, estilísticas y su proceso constructivo de mezquita a catedral: Pérez 1984, pp. 72-85; Delgado 1987, pp. 266-274; Franco 1991, pp. 409-465; Barbé 1992, pp. 152-163; Pérez 1998, pp. 18-107; Gonzálvez 2010, 142-147; Nickson 2010, pp. 148-161; Carrero 2011b, pp. 185-200.

${ }^{10}$ Domínguez 1984, pp. 73-75.

${ }^{11}$ Hernández 1985, p. 327, doc. 362.

${ }^{12}$ Ortíz 1999, pp. 228-230. Una recopilación de textos en: Castillo 2001, pp. 175-202, esp. 192-194.
} 
La devoción al Espíritu Santo Paráclito, recordado en el mismo documento de fundación de capellanías de julio de 1238 de Jiménez de Rada, formaba parte del culto mozárabe y a la vez era la figura símbolo de la renovación. El arzobispo pretendía la unión de su iglesia, y aunque defensor del rito de Roma, debía de mediar entre los clérigos de su diócesis partidarios bien del rito romano, bien del hispano o toledano. En febrero de ese mismo año, los eclesiásticos mozárabes se oponen a participar en la procesión en honor de san Eugenio, primer arzobispo de Toledo y evangelizador de la ciudad, por considerarlo un símbolo del dominio francés, y es significativo que ninguna de las 14 capillas instituidas ese mismo año lo fuera bajo la advocación de san Eugenio, y se dedicara la central a san Ildefonso, un santo local ${ }^{13}$. El culto al Espíritu Santo entroncaba con los dictados del IV Concilio de Letrán al que había asistido Jiménez de Rada, y centraba la atención sobre el dogma de la Trinidad, que se postula en el XI Concilio de Toledo (675), y era al Espíritu Santo Paráclito al que se invocaba en la fiesta de Pentecostés dentro de la liturgia mozárabe. Además tanto la vida de Cristo, como la figura de los apóstoles, mártires, confesores, vírgenes y profetas aparecen en la fundación de las catorce capellanías de la catedral de Toledo como en el programa iconográfico de la iglesia de san Román, símbolo de la liturgia mozárabe, y consagrada por el mismo arzobispo en $1221^{14}$. Todo ello define el área de la girola toledana como uno de los lugares de mayor complejidad histórica al unir la voluntad de exaltación dinástica regia ${ }^{15}$ y la concordia entre el culto romano y mozárabe en la diócesis de Toledo.

En 1215 Jiménez de Rada acudía a Roma al Concilio de Letrán, en cuya agenda había conseguido inscribir la cuestión de la primacía de Toledo disputada por los metropolitanos de Santiago de Compostela, Tarragona y Braga. Los inicios de la nueva catedral gótica de Toledo se fechan en 1226, poco después de la consagración de la iglesia de san Román. En 1926 el investigador Estella publicaba la traducción del decreto de 1238 por el que Jiménez de Rada dejaba instituidas catorce capellanías. En el preámbulo enuncia el Credo de los Apóstoles y continúa con la advocación de las capellanías:

yo Rodrigo, Arzobispo de Toledo, Primado de las Españas, con asentimiento y aprobación de todo el Cabildo toledano, instituyo en los altares de la nueva obra, que en mis días comenzó, a construirse desde la primera piedra, catorce capellanías: una en el altar

\footnotetext{
${ }^{13}$ Hernández 1992, pp. 79-93; Baron 2008; Hernández 2003, pp. 15-71.

${ }^{14}$ Abad 2004, pp. 20-44; Dodds, Menocal, Krasner 2008, pp. 163-189.

${ }^{15}$ Sobre la ubicación de estos sepulcros en una capilla del transepto norte y los sepulcros regios de la catedral de Santiago de Compostela, recientemente, con bibliografía anterior. Boto 2010, pp. 275-286; García González 2013, pp. 973-994; Carrero 2013, pp. 19-52.
} 
de la santísima Trinidad (1); otra en el de la santa Natividad (de Jesucristo) (2), en el de la Santa Aparición (3, unos citan Epifanía, otros Transfiguración), otra en el de la Santa Pasión (4); otra en el de la santa Resurrección (5), en el de la Santa Ascensión (6), en el del Santo Espíritu (7), en el de San Ildefonso de la Bienaventurada Virgen (8), en el de los Ángeles (9), en el de san Juan Bautista y todos los Patriarcas y Profetas (10), en el de todos los Apóstoles y Evangelistas (11), en el de todos los Mártires (12), en el de todos los Confesores (13) y en el de toda las Vírgenes $(14)^{16}$.

En una observación a estas advocaciones se aprecia como este plan litúrgico-dogmático de Jiménez de Rada no se adecua a la primitiva advocación de las capillas de la cabecera ${ }^{17}$. Varios investigadores han llegado a la conclusión de que en este documento de 1238 el objetivo de Jiménez de Rada era prestigiar a la catedral primada a través de la existencia de un proyecto litúrgico desde los mismos inicios de la construcción gótica ${ }^{18}$. En este texto de 1238 añadía la institución de tres capellanías más, por el alma de Alfonso VI, que ganó Toledo; otra por Alfonso VIII, vencedor de la batalla de las Navas de Tolosa; y finalmente una tercera por el monarca Fernando III y su madre doña Berenguela $^{19}$, ganándose así también el apoyo regio.

En el proyecto litúrgico-teológico y político de Jiménez de Rada para la catedral de Toledo también se encontraba la intención de definirla como la catedral primada de España, frente a las otras dos grandes catedrales: Santiago y Tarragona. En un análisis de estas sedes se advierte como originariamente ambas tenían el espacio absidial dividido en dos zonas. Esta disposición responde a varios motivos, y ha tenido diversas denominaciones según su uso y función, como las de retroaltar, trasaltar, altar matinal o relicario, como atestiguan los ejemplos de las capillas dedicadas a la Magdalena en Santiago de Compostela, san Fructuoso en la de Tarragona, o de la Santa Cruz en Toledo ${ }^{20}$. En Toledo este trasaltar conservaría las reliquias traídas por el arzobispo don Bernardo de Sauvetat de Roma, y además en 1248 recibiría unas prestigiosas

\footnotetext{
${ }^{16}$ Estella 1926, pp. 171-172; Hernández 1985, pp. 403-405, doc. 450.

${ }^{17}$ Como sucede en otras catedrales, lo habitual es que la nueva construcción conviviera con la antigua, bien una mezquita, bien el edificio románico, y que coexistan capillas de una época y otra, en una zona u otra del templo. Sobre la existencia de capellanías en la mezquita: Hernández 1985, p. 313 , doc. 348 .

${ }^{18}$ Hernández 2003, pp. 29-33. Nickson en la misma línea considera que los trabajos en la zona de la cabecera ya estaban terminados, y aunque una reducida parte de estas fundaciones sobreviviría, el documento debe considerarse como una expresión de confianza del éxito de la construcción (Nickson 2010, p. 149).

${ }^{19}$ Estella 1926, pp. 177-178; Hernández 1985, pp. 278, 403-405, docs. 301, 450. Sobre Alfonso VIII en el monasterio de las Huelgas: Pérez 2002, pp. 19-41.

${ }^{20}$ Carrero 2011a, pp. 65-80. Se tienen noticia de esta misma situación en Barcelona, Lleida, Gerona (Español 2005, pp. 213-232), y Mallorca (Carrero 2005, pp. 49-75).
} 
reliquias de Constantinopla (por donación de san Luis, rey de Francia) y este espacio se convertiría en un área sagrada de gran relevancia ${ }^{21}$. En la catedral de Santiago de Compostela tras el altar mayor se ubicó un altar matinal para devoción del santo y preservación de las reliquias ${ }^{22}$. En el Libro 26, capítulo 6 de la Historia De Rebus Hispaniae de Jiménez de Rada se narra que la catedral de Toledo fue consagrada el 8 de noviembre de 1086 en honor de santa María siempre Virgen, y de los santos Apóstoles san Pedro y san Pablo, y de la Santa Cruz, y también de san Estevan protomártir, y sobre el altar mayor se colocaron muchas y valiosas reliquias procedentes de la sede apostólica, más las donadas por el rey y la reina de su tesoro ${ }^{23}$. La devoción a la Santa Cruz constaba como referencia de la titularidad de la iglesia en época visigoda y en la fundación de la primada en 1086, así al dedicar el trasaltar mayor a la Santa Cruz reuniendo las reliquias cristológicas más importantes de la primada, se recordaba los orígenes cristianos de Toledo, y se vinculaba al culto hierosolimitano y a la cruz (como estandarte regio que guiaba a las tropas cristianas durante la conquista).

\section{SANCHO IV Y SU ENTERRAMIENTO EN LA DIVES TOLETANA}

Desde finales del s. XIII los monarcas castellanos muestran su voluntad de ser enterrados en el interior de los templos catedralicios, específicamente junto al altar mayor. El enterramiento regio en catedrales hispanas no era una idea nueva ni divergente en la tradición monárquica, el cambio es el nuevo emplazamiento ante el mismo altar mayor y su pretensión de crear una capilla o ámbito privado y particular donde reposen sus restos y se desarrollen las ceremonias que garantizaran su salvación ${ }^{24}$. Esta aspiración pretendía perennizar su memoria y mantener su linaje. La multiplicidad de recintos funerarios de época medieval y la ausencia de exequias protocolarias son características que explican que Alfonso X el Sabio escogiera su sepulcro funerario y el de sus padres, Fernando III y Beatriz de Suabia, en la catedral de Sevilla, Fernando IV se enterrara en la catedral de Córdoba, o Sancho IV en la Toledo ${ }^{25}$. El avance

\footnotetext{
${ }^{21}$ Carrero 2009, pp. 159-171.

${ }^{22}$ Carrero 2013, pp. 19-52.

${ }^{23}$ Jiménez de Rada 1989, p. 251; Ortíz 1999, p. 145.

${ }^{24}$ Bango 1992, pp. 93-132; Boto 2010, pp. 275-309; Boto 2012, pp. 535-565.

${ }^{25}$ Entre las últimas referencias: Ruiz 2006, pp. 9-29; Boto 2012, pp. 535-565. Sobre los ceremoniales y exequias regias hispanas: Arias 2006, pp. 49-80; Pérez 2007, pp. 379-394; Español 2007, pp. 867-905; Alonso 2010, pp. 115-148; Pérez 2011, pp. 213-244; 2014, pp. 487-516; Laguna 2005, pp. 73-87; 2012, pp. 177-233; 2013, pp. 127-157; Nogales 2014; Arias 2015 , pp. 643-675.
} 
en la conquista del territorio peninsular por ambas coronas, la existencia de varias líneas dinásticas durante el periodo medieval, el fallecimiento de los monarcas en diferentes regiones, o la confianza depositada en los hechos memorables de su reinado y no en el lugar en el que se depositen los restos de sus antepasados, son algunas de las ideas que se pueden exponer y explican esta situación.

El templo toledano siempre estuvo vinculado a la vida y el reinado de Sancho IV, puesto que en la catedral se desposó con María de Molina en 1282 y fue coronado rey en 1284 . En 1285, al poco tiempo de haber ascendido al trono castellano, Sancho IV decide ser enterrado en el altar mayor de la catedral de Toledo, culminando un proceso de aproximación de las capillas funerarias regias a los presbiterios de las iglesias iniciado por sus antecesores, y aprovechando el proyecto litúrgico-teológico y político desarrollado por Jiménez de Rada en la zona de la cabecera. Su elección debía recaer en una de las grandes catedrales castellanas, la ruptura de las relaciones con su padre Alfonso X le impedían vincularse a Sevilla, y el recuerdo de antecesores como Alfonso VII y la importancia de Toledo como sede primada fueron posiblemente motivos de suficiente peso para su elección en fechas tan tempranas de su reinado. Sancho IV buscando marcar una nueva línea de legitimación y tras decidir su enterramiento en la catedral, en 1289 trasladará de la capilla del Espíritu Santo a la capilla de la Santa Cruz, donde deseaba ser enterrado, los sepulcros de Alfonso VII el Emperador, Sancho III el Deseado y Sancho II Capelo de Portugal. La disposición original del ámbito presbiterial en dos espacios hizo que se vinculase a la capilla más oriental conocida como de la Santa Cruz, destinada a preservar las más santas reliquias de Cristo, y se reservase la más occidental como altar mayor y uso capitular litúrgico dedicado al Salvador ${ }^{26}$. La cabecera de la catedral debía de haberse finalizado hacía pocos años, y gozaba de un espacio privilegiado prácticamente intacto lleno de reliquias y evocador del Santo Sepulcro ${ }^{27}$, para disponer su sepultura y la de sus antecesores, ambicionando un enclave monumental que preservara su memoria y linaje. Las empresas artísticas enaltecedoras de su dinastía realizadas por su padre Alfonso X el Sabio marcaron la vocación posterior y el creciente deseo de superación por parte de Sancho IV por legitimar su poder y ascen-

\footnotetext{
${ }^{26}$ Sobre la originaria disposición de la capilla mayor: Pérez 2005, pp. 119-122, 385-391. Con una dimensión más amplia, y la hipótesis de no considerar la cripta de la época de Sancho IV: Gutiérrez 1997, pp. 163-194. El traslado de los enterramientos fue el 21 de noviembre de 1289. En esta capilla fueron reubicados también los restos del rey Sancho II de Portugal, del arzobispo infante Sancho de Aragón († 1275), y parece que también el arzobispo Sancho de Castilla. Posteriormente fue enterrado el infante Pedro de Aguilar $(\dagger 1338)$.

${ }^{27}$ Rivera 1985, pp. 127-133; Domínguez 1984, pp. 73-75; Azcárate 1990,p. 38; Torija 2014 pp. 283- 295. Fue Gutiérrez quien primero vinculó la capilla de la Santa Cruz con el edificio del Santo Sepulcro (Gutiérrez 1997, pp. 163-194; Pereda 2005, pp. 21-52; Ruiz 2006, pp. 9-29). En un contexto más amplio: Bango 1992, pp. 93-132; Boto 2010, pp. 275-309.
} 
dencia. Para esto, contó seguramente con el beneplácito del cabildo toledano para albergar sus restos, que vería así reforzada la importancia de la primada frente a las nuevas catedrales de las ciudades conquistadas que salvaguardaban los restos de monarcas. Posiblemente con este acto culminaba una de las empresas políticas más ambiciosas de Jiménez de Rada: afianzar la importancia de la catedral primada de España a través del apoyo monárquico y el enterramiento regio en el interior del templo.

La otra de las principales razones que ejercía el Templo del Santo Sepulcro y sus imitaciones es la de templo de reliquias. A través de estas edificaciones se pretendía evocar en el fiel el lugar santo de Jerusalén. En el estudio de las reliquias de la catedral primada destacan las llegadas con su fundación alrededor de 1086, y principalmente las donadas por el rey san Luis de Francia alrededor de 1248 entre las que se encuentran fragmentos del Lignum Crucis, de las espinas de la corona de Cristo, leche de la Virgen María, de la túnica de púrpura de Cristo, de la toalla que Jesús se ciñó y lavó los pies a los apóstoles durante el viernes santo, de la sábana con la que se envolvió su cuerpo en el sepulcro y de los paños de su infancia ${ }^{28}$. Además de las anteriormente citadas una de las piezas más importantes es el relicario del monarca san Luis de Francia, que albergaba las reliquias de san Cristóbal, san Esteban, san Laurencio, san Alejo, san Damián, san Eugenio, san Dionisio, san Cosme, san Félix, velo y vestido de la Virgen María, san Luís, santa Ana, san Juan Bautista, san Leonardo, san Bonifacio, vestido y árbol en que oraba San Francisco, san Bartolomé, santo Tomás Arzobispo Canturiense, santa Bárbara, Sansón Confesor y santa Marina, y podría haber actuado como el Arca de la Alianza del templo primado, semejante al Arca de la Alianza del templo de Salomón. Todas estas piezas seguramente fueron donadas por el rey francés quizás junto a otro gran tesoro de la catedral, la Biblia Moralizada en 3 tomos, o de san Luis. No están claros los motivos exactos por los que el francés hizo esta donación, pero además del acto de dádiva que implicaría el fortalecimiento de los lazos de amistad, en la posesión de los monarcas castellanos de unas preciadas reliquias de la vida de Cristo habría que recordar a Blanca de Castilla, madre de san Luis, o incluso los acuerdos matrimoniales pactados entre san Luis y Alfonso X para miembros de sus familias.

En la comprensión de este espacio cultual es significativo asimilar su proceso evolutivo, puesto que el archivero y canónigo de la catedral Ramón

${ }^{28}$ Ortíz 1999, pp. 196-198. Sobre la importancia de las reliquias y su vinculación con Jerusalén: Morris 2005. Tampoco se puede saber con seguridad si es el deseo de emular alguno de los edificios de Tierra Santa o la llegada de unas reliquias cristológicas lo que fomenta estas relaciones simbólicas, iconográficas o formales de edificios de Occidente con monumentos hierosolimitanos (pp. 223-245), o más bien confluyen ambas intenciones en un mismo ambiente que asocia el culto cristiano con la salvación del alma. 
Gonzálvez recuerda que Sancho IV no había fundado ninguna capilla, y que fue su nieto Alfonso XI quien instituyó la fundación de la capilla de la Santa Cruz en 1317, y en 1327 se encuentra la primera lista de los capellanes ${ }^{29}$. En 1289 Sancho IV en un privilegio rodado declara su deseo de ser enterrado en esta sacra capilla (fig. 6), a la que en esta fecha trasladará los cuerpos de los reyes Alfonso VII y Sancho III, para corroborar esta decisión y legitimar su lugar de enterramiento. Pero fue su nieto Alfonso XI, educado por María de Molina, esposa de Sancho IV, quien terminó de institucionalizar una devoción que ya contaba con una tradición anterior, puesto que desde 1248 las reliquias del Lignum Crucis y otras tantas ya se preservan en la catedral y, probablemente, en el espacio más sagrado, detrás del altar mayor, como sucedía en Tarragona y Santiago de Compostela.

\section{ESTRUCTURAS DIÁFANAS Y ADVOCACIONES SIMBÓLICAS}

El monarca Sancho el Bravo quería exaltar su linaje, ser admirado y recordado para la posteridad, por ello muy probablemente dispuso que los sepulcros se situaran en alto, como actualmente se aprecian, y además pudieran ser observados desde todos los puntos de vista. De hecho, la disposición semicircular de la capilla aún conserva alguno de sus paños abiertos consintiendo la mirada de los fieles: para la devoción a las reliquias y admiración a la monarquía. Hoy en día la parte inferior está ocupada por el trascoro, confeccionado a finales del s. XV y ocultando la imagen del interior, mientras que la zona superior de estos paños se encuentra tapiada y con una pintura de tracerías ciegas que aludiría a la visión diáfana existente en la zona de la cabecera (fig. 2). Las propias capillas radiales del deambulatorio de la catedral actualmente mantienen su acceso original formado por una tracería transparente que permite la visión de su interior, la oración a las almas y la admiración de unos espacios privilegiados, que imitarían el ámbito funerario más venerable de la catedral primada ubicado en la capilla de la Santa Cruz. Además, en un paseo por el espacio límpido del deambulatorio se comprueba la búsqueda de un área abierta y traslúcida, que alcanzaría desde las capillas radiales funerarias de don Álvaro de Luna o del Arzobispo Albornoz, como los ejemplos

${ }^{29}$ Gonzálvez 2010, pp. 104-110, esp. 105-106, refiere que no existe ningún documento fundacional, y aunque éste bien pudiera haberse perdido, es muy probable que las reliquias de la Santa Cruz preservadas en la capilla fueran el motivo por el que Sancho IV la escogiera como lugar de enterramiento (Franco, Mata 2010, p. 185). 


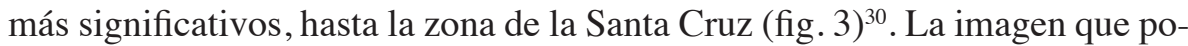
dría sugerir la cabecera es la que actualmente presentan las grandes catedrales con las que pretendía asemejarse Toledo, las de París, Bourges y Le Mans. El diseño de la costanera de santa Lucía podría ser un ejemplo similar de lo que pudo existir en el lado del evangelio, y que se transformó a principios del s. XVI con la remodelación del altar mayor ${ }^{31}$. El transparente barroco de Narciso Tomé fue la respuesta dada en época moderna a la visión del Santo Sacramento (y en época medieval a las reliquias) desde el coro y el deambulatorio, manteniendo una tradición de visibilidad y unas formas de diafanidad y sensación etérea de luminosidad que ya se daban desde los inicios constructivos de la catedral ${ }^{32}$.
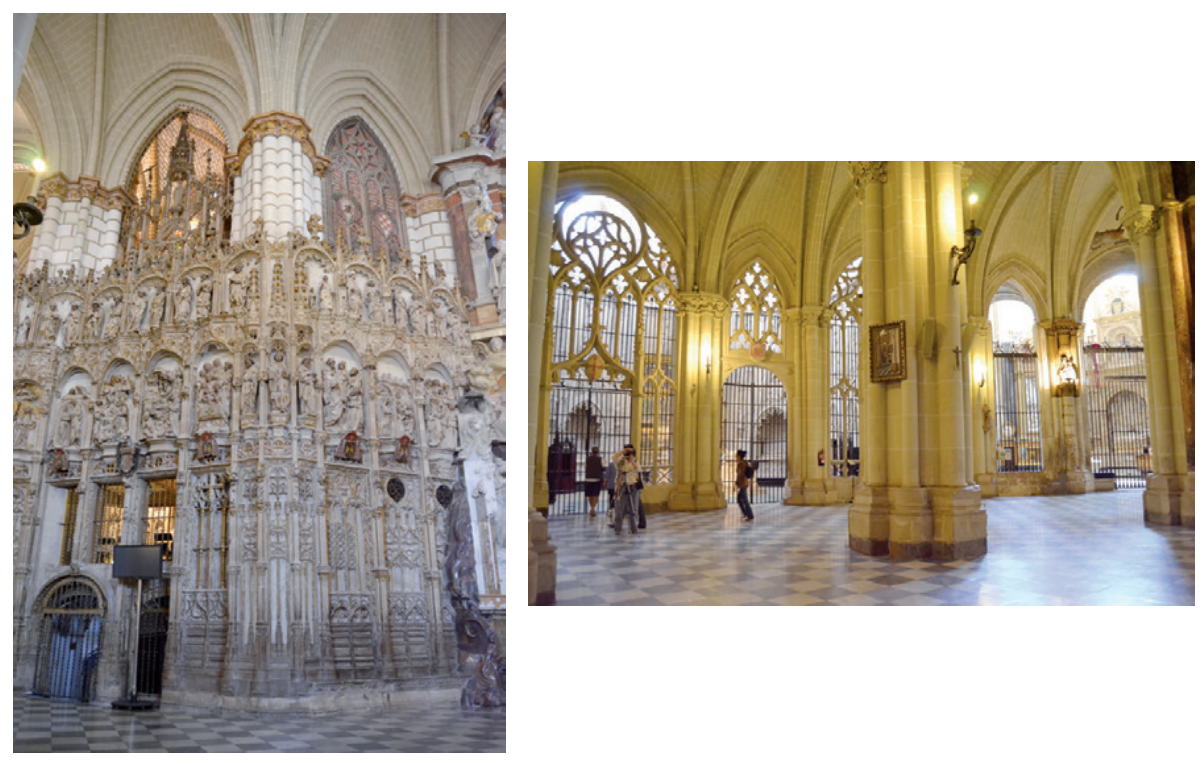

Figs. 2 y 3. Catedral primada de Toledo, deambulatorio. Foto de la autora.

\footnotetext{
${ }^{30}$ No es posible concretar en este estudio la existencia de unas tracerías caladas en la arcada de la capilla mayor, limítrofe con el deambulatorio, más allá de subrayar la unidad espacial que evocarían estos tres ámbitos.

${ }^{31}$ El sepulcro proyectado para el Cardenal Mendoza amenazaba esta visión unitaria, y es por ello que el cabildo mostró cierta resistencia a este proyecto, e incluso Francisco Jiménez de Cisneros, su sucesor, declaró su predilección por otro tipo de sepulcro más gótico, con "pilaretes y archetes" que seguramente mantendrían esta unidad visual. Díez 1987, p. 39.

${ }^{32}$ Similar idea había sido expuesta a partir de la existencia de un primer transparente, en Pérez 1993-1994, pp. 471-480. Sobre el transparente barroco: Ayala 1969, pp. 255-288, especialmente las primeras páginas; Prados 1976, pp. 387-416.
} 
El primer espacio que observaba el fiel al dirigirse al altar mayor a principios del s. XIV era la capilla mayor, presidida por un magnífico retablo de 13 metros de ancho y 4 metros de alto, encargado originariamente en 1387 a Esteve Rovira de Chipre por el arzobispo Pedro Tenorio ${ }^{33}$ (fig. 4). Este muro retablístico dividía el espacio presbiterial entre la capilla mayor, donde se celebraban habitualmente las ceremonias litúrgicas de la catedral, y el dedicado al culto a las reliquias y funerario de Sancho $\mathrm{IV}^{34}$. Según la tradición el altar mayor estaba dedicado al Salvador, es decir, la advocación más habitual en lugares de reconquista y de convivencia entre pueblos de diferentes religiones, como es el caso de Toledo. En un sugerente artículo, el profesor Arciniega reclama la atención sobre el significativo número de iglesias y catedrales, especialmente aquellas mezquitas convertidas al culto cristiano, dedicadas a Jesús como mesías Salvador ${ }^{35}$. Además bajo la devoción del Salvador coinciden otras importantes circunstancias como la referencia a Constantino, el primer emperador cristiano, que venció en el puente Milvio; recuerdan las palabras veterotestamentarias que anunciaban al Dios de Israel como el salvador del pueblo elegido; y la iglesia de San Juan de Letrán o del Salvador, la más importante de Roma, e iglesia del Papa. Es decir, toda una serie de alusiones directas que Jiménez de Rada debió tener muy en cuenta dentro de su proyecto cultural y político.

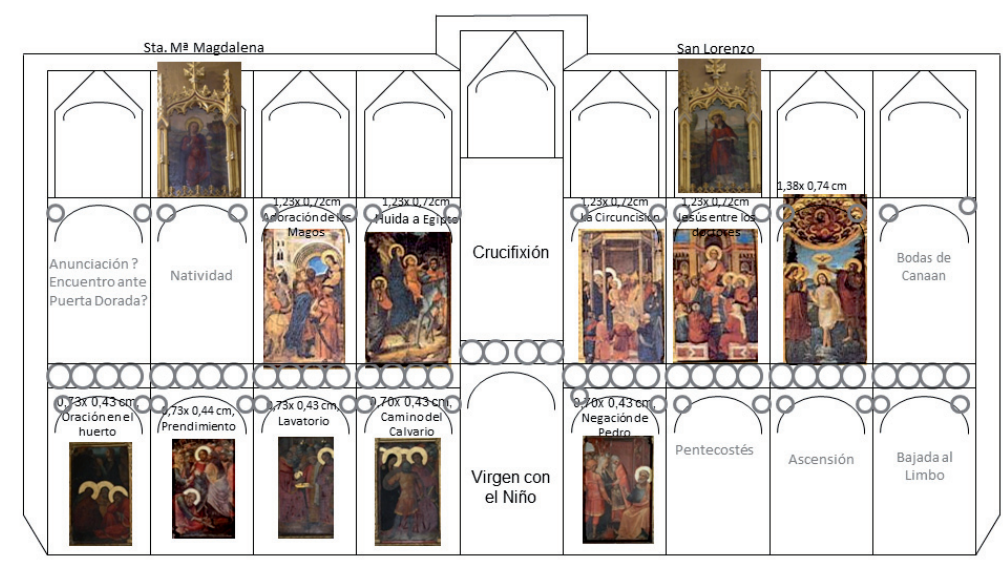

Fig. 4. Esteve Rovira de Chipre y taller (atribuido), Primitivo Retablo mayor de la Catedral de Toledo, Reconstrucción hipotética, ca. 1388-1419.

\footnotetext{
${ }^{33}$ Miquel 2013, pp. 2700-2720.

${ }^{34}$ Sobre el doble uso litúrgico y funerario de los espacios religiosos, y en concreto del altar mayor: Gaier 2006, pp. 153-180.

${ }^{35}$ Arciniega 2012, pp. 71-94.
} 
Centrándonos en este segundo ámbito se ha de recordar que probablemente estaba elevado, como las otras capillas funerarias regias, y actualmente recuerdan las escaleras conservadas que permitían la existencia de los dos espacios. Esta prominencia ejercía una doble función, por una parte determinaba la presencia de una cripta, y a la vez, exaltaba las reliquias de la capilla funeraria regia de Sancho IV definida en alto con respecto al resto del edificio $^{36}$ (fig. 5). Aunque no hay noticias claras ni definitivas sobre la doble altura de este espacio, hay autores que rechazan esta propuesta por falta de pruebas concluyentes, mientras que el estudio de otros espacios similares es considerado por otros investigadores como una hipótesis acertada de trabajo ${ }^{37}$.

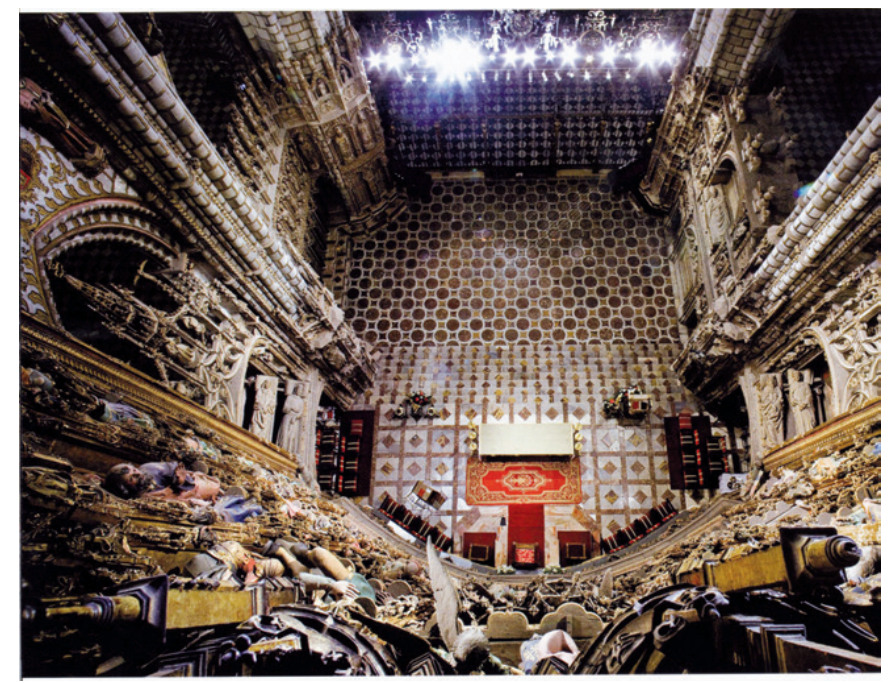

Fig. 5. Catedral primada de Toledo, capilla mayor, visión cenital. Imagen tomada de Gonzálvez Ruiz, Ramón (coord.), La Catedral Primada de Toledo, Toledo, Promecal.

Además, estas alusiones conectaban con una de las empresas literarias más importantes promovidas durante el reinado de Sancho IV: La Gran Conquista de Ultramar. La evocación del templo del Santo Sepulcro en un

\footnotetext{
${ }^{36} \mathrm{La}$ existencia de dos alturas conecta con la estructura doble de capillas funerarias y de reliquias creadas por las monarquías europeas en sus palacios y residencias (Billot 1998; Grabar 1947). En la Península Ibérica, con bibliografía anterior: Serra, Miquel 2009, pp. 65- 80.

${ }^{37}$ Remito a la bibliografía citada en la nota 27 , y añado los acertados comentarios de la doctora Franco (Franco 2010, pp. 189-191). Antiguas referencias sobre la existencia de unos escalones, que no una cripta (Campoy 1929, pp. 112-118).
} 
edificio castellano no era un unicum en la Península Ibérica ni en Europa, y además, la escuela catedralicia de Toledo es considerada uno de los focos intelectuales más importantes de la España medieval ${ }^{38}$. Miembros de esta elite próxima al rey son autores de libros como el Lucidario, el Libro del Caballero Zifar, la Crónica de los Reyes de Castilla o Los Castigos y documentos del rey don Sancho, que definirán una literatura y conocimientos sobre el mundo conocido y los intereses regios de Sancho IV.

Una imagen del ámbito presbiterial puede encontrarse en el privilegio rodado de Sancho IV (1285) donde expresa su deseo de ser enterrado en la catedral (fig. 6). La iluminación no es una representación ajustada en todos sus detalles de la sede primada pero su observación proporciona datos significativos como la estructura del templo en cinco naves, y más concretamente la dualidad de los espacios ocupados por la capilla mayor y la de la Santa Cruz. Ante el altar de la Santa Cruz aparece la efigie sedente del monarca con el orbe en una mano, y con la otra señalando seguramente el sepulcro de Alfonso VII, junto al que pretende ser enterrado, según reza el documento. Al otro lado, el arzobispo Gonzalo Pétrez (1280-1299), bendiciendo la empresa, todo ante el altar mayor presidido por la escultura de la Virgen (seguramente la Virgen del Sagrario) ${ }^{39}$.

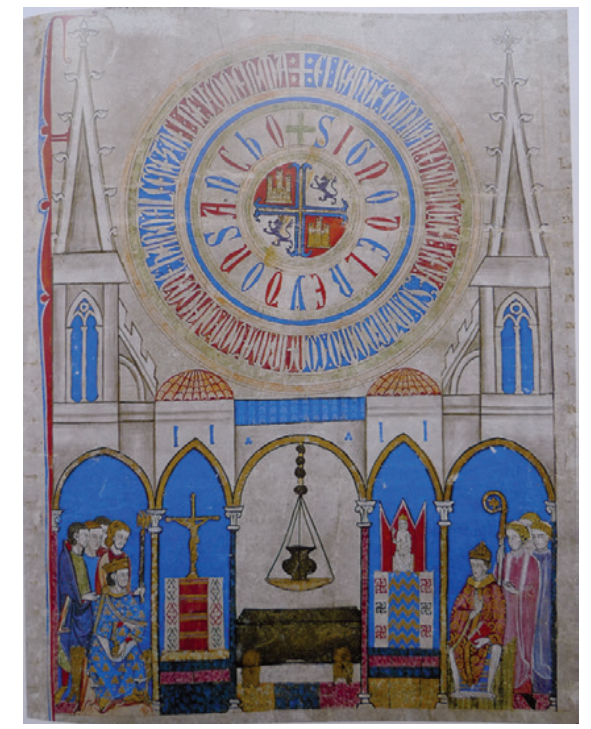

Fig. 6. Privilegio rodado del rey Sancho IV, Testamento de Sancho IV, 1289, Archivo Histórico Nacional, Clero 3022/5bis, Madrid.

\footnotetext{
${ }^{38}$ Gonzálvez 1997; Orduna 1996, pp. 53-62; Alvar, Lucía 2002, pp. 603-608.

${ }^{39}$ Gaite 2001, p. 137.
} 


\section{LA ORNAMENTACIÓN: ENTRE APÓSTOLES Y RELIQUIAS}

Resulta interesante valorar el retablo mayor de la catedral de Toledo como mediador de los dos espacios con una posible función de retablo doble. Si en la capilla mayor la iconografía del conjunto remitía a la vida de Cristo, desde la infancia hasta los hechos de la Pasión ${ }^{40}$, actualmente en la cripta del Santo Sepulcro de la catedral de Toledo se conservan dos tablas de los apóstoles Simeón y Juan, similares a un san Judas Tadeo, actualmente en el Vassar College Art Gallery- the Frances Lehman Loeb Art Center (Poughkeepsie, Nueva York) (aproximadamente 1,92 -con mazonería- o 1,65x0,74 cm). La mazonería de estas tablas de los apóstoles es igual que la existente en el retablo de san Eugenio (concretamente la tabla del Bautismo que conserva casi integra la mazonería), que se ha identificado como el retablo mayor de la catedral de Toledo. Se desconoce la ubicación exacta de estas piezas que seguramente formaban parte de toda una serie completa de los apóstoles, lo que alcanzaría una amplitud de más de 9 metros. Su elevada altura, de tamaño natural, impide vincularlas al retablo mayor visible en el altar mayor, pero sería muy adecuado disponerlo en la parte trasera de este conjunto y formando parte de la capilla de la Santa Cruz (fig. 7). Así, se podría pensar en una estructura bifronte que ejercería una doble función, y supondría la culminación formal y temática del retablo a finales del s. XIV. El formato horizontal en un retablo destinado al altar mayor de una catedral suponía en estas fechas un ejemplar ciertamente anticuado, pero tanto la funcionalidad de muro pantalla con la peculiaridad de permitir la visión de los sepulcros regios elevados en la capilla superior de la Santa Cruz, como su distintiva estructura doble adaptada a los dos ámbitos absidiales adquiría significado dentro del uso litúrgico. La necesidad de celebrar ceremonias en la capilla de la Santa Cruz de propiedad regia, y a la vez en la capilla principal de uso capitular, predispone positivamente a considerar la existencia de este dispositivo pictórico doble con dicha estructura y funcionalidad. Las escenas de la pasión de Cristo se relacionan con el programa litúrgico, la celebración de la misa y las horas canónicas de la capilla mayor, mientras que el apostolado vendría a incidir en el carácter hierosolimitano y funerario de la capilla de la Santa Cruz.

${ }^{40}$ Miquel 2013, pp. 2700-2720. 


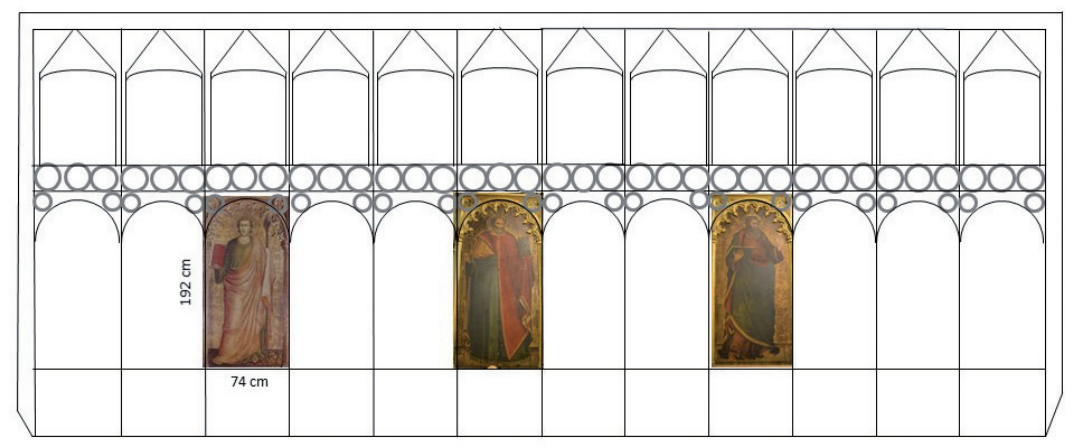

Fig. 7. Esteve Rovira y taller (atribución), Retablo mayor de la catedral de Toledo, reverso.

Reconstrucción hipotética, ca. 1388-1419.

En el planteamiento de esta hipótesis de trabajo no se puede avanzar en el tipo de trabazón interna de las dos partes, o las dimensiones exactas del muro entre ambos lados, más bien se pretende argumentar la existencia de una estructura pictórica bifronte destinada a dos espacios litúrgicos paralelos ${ }^{41}$. La presencia de todo un apostolado, visible desde la girola y alrededor de los paños abiertos, refuerza la advocación y simbolismo de esta capilla funeraria de la Santa Cruz al rememorar la Jerusalén celeste, la evocación del Calvario y la conmemoración del Santo Sepulcro donde fue enterrado Cristo. Igualmente se ha de recalcar la existencia de doce capellanes menores y un capellán mayor encargados de la capilla de la Santa $\mathrm{Cruz}^{42}$. Estas referencias directas a los apóstoles reforzaba el carácter martirial de la capilla al rememorar otro de los sagrados edificios alusivos del Santo Sepulcro, la iglesia de los Santos Apóstoles de Constantinopla, templo funerario de Constantino ${ }^{43}$, y en una cronología más cercana, la Sainte-Chapelle de París, capilla de reliquias de la monarquía francesa, decorada con reyes bíblicos, apóstoles y escenas de la Pasión de Cristo ${ }^{44}$.

La decoración escultórica interior de la capilla mayor de la catedral de Toledo en la actualidad la conforma toda una amalgama de esculturas de

\footnotetext{
${ }^{41}$ Un ejemplo similar vinculado a este mismo uso doble es el que proporciona el retablo doble de la Maestà de Duccio di Buoninsegna, la pala d'oro de la basílica de San Marcos de Venecia o el políptico Stefaneschi de Giotto (Seiler 2002,pp. 252- 269). La bibliografía sobre la Maestà de Duccio es abundante, con bibliografía anterior, y otros ejemplos de retablos dobles: Gordon 2002, pp. 229-249.

${ }^{42}$ Gutiérrez 1997, p. 168.

${ }^{43}$ Ousterhout 2006, pp. 98-116, donde destaca el trinomio reliquias, espacios funerarios y ceremoniales.

${ }^{44}$ Billot 1987, pp. 229-248; 1998; Hediger 2007.
} 
diferentes tamaños y etapas cronológicas, posiblemente coherentes con las fases de reforma cultual del templo. Muchas de estas esculturas se han relacionado con los reyes y arzobispos que rigieron la sede durante la construcción de la catedral. La investigadora Franco difiere y más bien considera que los reyes, prelados y santos, ángeles portadores de una corona real y tres palomas en manos de dos ángeles (ocultos tras el retablo) se relacionan con los asistentes a la ceremonia de coronación de Sancho $\mathrm{IV}^{45}$. Resulta imposible en este artículo establecer un análisis formal, iconográfico y estilístico de las obras, agruparlas y avanzar en su conocimiento pero, tal y como ya se ha advertido, muchas de las esculturas de la capilla real se relacionan con las existentes en la puerta del reloj, fechadas alrededor de 1309-1310, y con el acto de fundación de la capilla real como capilla de la Santa Cruz en 1317 por Alfonso XI. Años en que se pudieron añadir muchas de las imágenes de personajes regios y sacerdotes dentro de un programa de representación monárquica de legitimidad y reivindicación dinástica que Alfonso XI habría programado evocando el linaje regio y la estirpe de Cristo. Hoy en día junto al sepulcro del cardenal Mendoza, en el pilar del Alfaquí y también en el del Pastor, se ubican esculturas de reyes, prelados y sacerdotes; la originaria costanera de Santa Lucía está ornamentada con figuras de prelados (lado interno) y apóstoles (lado exterior); en el otro lado -actual sepulcro del cardenal Mendoza- se representarían reyes y quizás sacerdotes de la Antigua Ley, que reflejan un programa iconográfico de mayor ambición al que originariamente se ha considerado ${ }^{46}$. Todas estas esculturas, más las dispuestas en la parte alta del triforio en la cabecera, remiten a diferentes periodos y momentos cronológicos. La evocación de sus antepasados y de reyes de la Antigüedad forma parte de la cultura regia visual más significativa de los monarcas europeos de estos siglos ${ }^{47}$, pero además se ha de recordar que uno de los manuscritos que formaba parte de los bienes más preciados de Alfonso XI es El libro de las Semblazas de reyes (Biblioteca Nacional, ms. 7415) que bien pudo influir en la confección de este repertorio de antepasados en la capilla funeraria de su abuelo alusiva al Santo Sepulcro. El Libro de las Semblanzas de Reyes, fechado alrededor de 1320 en la corte

\footnotetext{
${ }^{45}$ Franco 2010, pp. 180-225, esp. 180-189.

${ }^{46}$ Además, otras esculturas de reyes se han propuesto considerarlas como parte de la decoración escultórica de la capilla de Santa Cruz (Gutiérrez 1997, pp. 177-180, con bibliografía coincidente con esta teoría). Parro indica que en el lado del evangelio se debían de representar reyes en la parte interna, y prelados alternados con santas en la exterior, y refiere la sucesión de esculturas de monarcas en toda la zona de la cabecera que aludirían a los antepasados regios a modo de memorial regio (Parro 1978, pp. 131-136, véanse las notas a pie de página). Sobre las esculturas funerarias: Pellón 2009, pp. 67-81.

${ }^{47}$ Está presente en el encargo de Luis IX, rey de Francia, en el templo relicario de la SainteChapelle de París (con bibliografía anterior: Hediger 2007). Véase también: Voelkle, Docampo, Pérez 2015.
} 
castellana, seguramente bajo el patrocinio de María de Molina, esposa de Sancho IV y regente del reino durante la minoría de edad de su nieto Alfonso XI, sirvió como libro de formación del futuro monarca. Los precedentes en los que se han reconocido las fuentes de confección del citado manuscrito revelan unos fuertes contactos con el ámbito toledano que demuestran no ser ajenos a la representación de los antepasados regios y a las genealogías de reyes ${ }^{48}$.

En un análisis de las reliquias conservadas en la catedral de Toledo se constata su elevado número y sobre todo la importancia de dichos santos objetos $^{49}$. Y si leemos la descripción de reliquias de Ortíz en 1549 se añaden otras muchas reliquias ${ }^{50}$. Debido a su gran cantidad parece que se preservaban en diferentes espacios catedralicios: en el sagrario del altar mayor ${ }^{51}$, en el sagrario donde posteriormente se edificaría el conjunto de sagrario y ochavo que actualmente se conserva ${ }^{52}$, en la sacristía ${ }^{53}$, y en las capillas donde se veneraba el santo o la advocación relativa a la reliquia, como sucedía en la capilla de San Ildefonso, o en la capilla de la Santa Cruz. Tal cantidad de reliquias, y especialmente las conservadas en el sagrario de la capilla de la Santa Cruz, debieron de exponerse en un mueble ostensorio acorde con su importancia y con el ceremonial de exhibición y ocultación de los rituales litúrgicos de la catedral primada.

Contamos con un documento inédito excepcional, por su conservación y temprana cronología en tierras castellanas, relativo al contrato de un retablo de reliquias para el sagrario de la catedral de Toledo en 1418. El 20 de julio de 1418 el racionero de la catedral, Alfonso Mestre, acuerda con el

${ }^{48}$ Rodríguez 2006, pp. 219-231. Entre los precedentes formativos del manuscrito 7415 se refiere el Liber Regnum, uno de cuyas versiones está fechada en 1220 y sirvió de fuente a Jiménez de Rada para su De Rebus Hispaniae (p. 223), y un manuscrito del De Rebus Hispaniae que se sabe perteneció a Jofré de Loaysa, arcediano de Toledo, cronista y diplomático en la corte de Sancho IV (p. 225). Indudablemente hay que citar como precedente los "retratos" del segundo volumen de la Estoria de España (Escorial, X.I.4) bajo el reinado de Sancho IV (Gonzálvez 1997, pp. 619-634).

${ }^{49}$ Puede leerse un repertorio de las piezas en: Revuelta 1989.

${ }^{50}$ Ortíz 1999, pp. 198-199. Otras descripciones que igualmente alaban la riqueza y cantidad de reliquias del Tesoro de la catedral: García Mercadal 1952, vol. I, pp. 462-463.

${ }^{51}$ Actualmente se refiere al espacio situado detrás del retablo mayor (Parro 1978, pp. 105-115), pero que debía de aludir a un espacio de reliquias anterior, vinculado a la capilla de la Santa Cruz, a la conservación del Lignum Crucis y reliquias.

${ }^{52}$ Según Ortíz el sagrario primitivo ocupaba las capillas de Santa Marina y San Andrés, y se dividía en el sagrario exterior y el interior (que albergaba un relicario ostensorio en su pared norte). Ortíz 1999, pp. 194-208; Parro 1978, pp. 532-540. Sobre el nuevo sagrario: Marías 1986, tomo III, pp. 193-207; Revuelta 1989, tomo II, vol. I, pp. 223-313; Suárez 1990, pp. 255 y ss.

${ }^{53}$ San Román 1920, pp. 121-125. El artículo únicamente cita el tesoro en el "revestiario" que se identifica con la sacristía y el sagrario. El inventario refiere principalmente piezas del vestuario y ajuar litúrgico, pero escasas reliquias. 
pintor Juan Alfonso, hijo de Joan Alfonso, vecino de Toledo, la confección de un armario y retablo para las reliquias del sagrario, de una fina obra de talla de madera, todo de oro bruñido, entrecalles con imágenes pintadas y buenos colores, por 16.000 maravedíes. Por la descripción se puede considerar que era un retablo con guardapolvo con espacios para guardar las reliquias, de ahí la denominación de armario, además tenía pintados los escudos del rey y del arzobispo, que en esas fechas era Sancho de Rojas. Los huecos para las reliquias estaban pintados en oro con decoración de águilas y estrellas, y el suelo que sostendría los relicarios sería de color rojizo. También se indica que el retablo tendría unas puertas pintadas de azul de Medina del mejor (y no de Acre) con sus grandes estrellas de oro, y cerrado tendría una ornamentación de lazo de color anaranjado. El tiempo estipulado de confección era de 5 meses, hasta el mes de diciembre, y los pagos se establecen en tres fases de cantidades equitativas de 5.333 maravedíes y 5 dineros, al comienzo, a mitad y cuando esté terminado. Pero se sabe que se retrasó puesto que tras el primer pago en la firma del acuerdo, los siguientes se sucedieron el 27 de noviembre (3.000 maravedíes), el 7 de diciembre (1.000 maravedíes), el 26 de enero de 1419 (2.000 maravedíes), el 6 de marzo (1.230 maravedíes) y finalmente el 2 de abril de 1419 , cuando se da por finiquitado el acuerdo con el abono de 3.436 maravedíes y 5 dineros $^{54}$. No se indican las dimensiones del conjunto, pero el precio es alto para valorarlo como una pieza de alta calidad y ricos materiales, o incluso una considerable extensión. Se podría recurrir para comprender la estructura, formato y uso del retablo-armario de reliquias de la catedral de Toledo al altar-relicario del Monasterio de Piedra, actualmente en el Museo de la Real Academia de la Historia en Madrid ${ }^{55}$, el del monasterio de Guadalupe ${ }^{56}$, y a los retablos calados de reliquias de la Corona de Aragón ${ }^{57}$.

Se desconoce el lugar donde estuvieron ubicados el sagrario y este retablo-relicario en el s. XV. La denominación de sagrario en el s. XV podía referirse a un tabernáculo, como un dosel que cobija el sagrario o el propio armario eucarístico, o incluso una alacena o espacio en la pared para ubicar a las reliquias, y no implicaba necesariamente la existencia de un espacio propio e independiente ${ }^{58}$. El documento del contrato no es concluyente y permite

\footnotetext{
${ }^{54}$ Archivo de la Catedral de Toledo, Libro de Obra, sign. 761 (1418), f. 155v. El 20 de julio el pintor Juan Alfonso cobra 5.333 maravedíes por la pintura del armario y del retablo de las reliquias del sagrario. Al no diferenciar entre uno y otro en la descripción, más bien parece que este retablo tendría la función de armario, con sus puertas para conservar las reliquias.

${ }_{55}^{55}$ González 2010, pp. 229-246; 2013, pp. 203-219. Agradezco el doctor González su ayuda.

${ }^{56}$ Nieto 2013, pp. 243-258.

${ }^{57}$ Español 2001, pp. 289-293; 2002, pp. 192-193.

${ }^{58}$ Español 2001, p. 290. En relación con este retablo de reliquias se ha de recordar la construcción de una capilla del Sacramento detrás del retablo mayor confeccionado a principios
} 
considerar el sagrario tanto un tabernáculo que preserva la Hostia consagrada (y reliquias), bien como una estancia independiente dentro del templo. Dentro de esta línea hay que valorar la alusión al escudo del rey en el contrato y el papel del relicario dentro del espacio funerario regio de la capilla de la Santa Cruz. Es igualmente indicativo de esta hipotética ubicación el hecho de que a finales del s. XV, cuando se está reformando toda la capilla mayor con un nuevo retablo, también se estén realizando obras en el llamado sagrario interior y exterior, posiblemente debido a la necesidad de un nuevo y amplio espacio para las reliquias y relicarios de la catedral tras la eliminación del emplazado en la capilla de la Santa $\mathrm{Cruz}^{59}$. A este respecto se puede recordar la comparación expuesta por Münzer en 1495 del sagrario interior y exterior (con pinturas de Antonio del Rincón y Pedro Berruguete confeccionadas entre 1483-1497), con la mismísima decoración de la Capilla Sixtina del Vaticano ${ }^{60}$. El aspecto y la gran cantidad de reliquias preservadas en la sede primada reflejan la importancia de estos objetos y su necesaria correcta exposición tras la reforma del altar mayor.

En la descripción de la catedral de Toledo de Ortíz fechada en 1549 refiere que en el sagrario interior había en la pared septentrional un:

relicario de madera, que guarda en urnas y en varias preciosas cajuelas y repositorios de plata inumerables reliquias de santos; de las quales son las principales las siguientes: tres pequeñas cruces del santísimo lignum crucis, en que Christo Nuestro Salvador estubo pendiente por la salud humana; la $1^{\text {a }}$ en una lámina de plata, cercada de margaritas y otras piedras preciosas, en la qual, puestos los sagrados evangelios delante, juran los prelados en la primera visita después de su asumptión al arzobispado de guardar los estatutos de esta sacrosanta basílica; la otra en una chapa grande de plata, circumbalada de muchas reliquias de santos y piedras preciosas de mucho valor; la $3^{\mathrm{a}}$ en el medio de una cruz. Guárdasse también dentro de una pequeña custodia de plata una espina de la corona del señor, la qual con otras preciosas reliquias, donó a la iglesia de Toledo san Luis rey de Francia ${ }^{61}$.

Es una posibilidad a contemplar que este relicario de madera fuera inicialmente el retablo de reliquias encargado en 1418 en la capilla de

del s. XVI con motivo de la reforma del altar mayor. Esta capilla trasera es uno de los motivos principales para considerar la existencia de un primer transparente en la catedral de Toledo: Pérez 1993-1994, pp. 472-476.

${ }^{59}$ Los pagos aparecen en la documentación en repetidas ocasiones, y hoy en día es posible verlo ya publicado gracias a la importancia de los pintores que en esta obra colaboraron (Marías, Pereda 2004, pp. 151-167, esp. 153-155, 162).

${ }^{60}$ García Mercadal 1952, pp. 247-253.

${ }^{61}$ Ortíz 1999, p. 196. 
la Santa Cruz y que tras la reforma el altar mayor se trasladase a la pared norte del sagrario interior. Con los datos que se tienen no es posible determinar que procediera del altar mayor de la capilla de la Santa Cruz o del primitivo sagrario principal de la primada, pero hay que valorar en su justa medida la importancia de las reliquias descritas originariamente vinculadas a la capilla de la Santa Cruz, tras el altar mayor, el emplazamiento más empleado y adecuado para disponer las reliquias durante el periodo gótico ${ }^{62}$.

En las capillas reales se conjuga el culto a las reliquias y la presencia de una imagen u objeto de devoción con la consideración de los cuerpos regios como imbuidos de la sacralidad que les rodea. El germen de esta idea que Alfonso X había llevado a un punto álgido con su padre Fernando III con las reliquias de san Leandro y la Virgen de los Reyes en Sevilla, pretende ser superada por su hijo Sancho IV con las reliquias cristológicas, el enterramiento de Alfonso VII y la Virgen del Sagrario. Dentro de estas escenografías regias de poder resulta interesante considerar el papel de los sepulcros dentro del ceremonial religioso, como sucede en el túmulo de Jaime II de Mallorca ${ }^{63}$, ubicado en la Vía Sacra.

Con la reforma del s. XVI se unificaron las capillas del Salvador y de la Santa Cruz y se construyó una nueva capilla mayor y retablo (1498-1504), eliminando el antiguo que fue desmembrado, y creando un nuevo espacio presbiterial. Este es uno de los principales problemas al que nos enfrentamos para dilucidar la estructura, composición y decoración original de la capilla mayor. A finales del s. XVI el cardenal Quiroga promueve la creación de un sagrario completo donde se preservaran todas las reliquias. El proyecto final no se realiza hasta mediados del s. XVII conformando la capilla del sagrario y el ochavo. Las transformaciones de la capilla mayor a principios del s. XVI y la eliminación de la capilla de la Santa Cruz, y así también su papel como espacio relicario, debieron de ser uno de los motivos que propiciaron la reforma del sagrario, que podría albergar ahora todas las reliquias de la catedral en un mismo espacio.

\footnotetext{
${ }^{62} \mathrm{Al}$ igual que se considera la Virgen del Sagrario como la originaria del primitivo altar mayor (Español 2013, pp. 117-134). Sobre la combinación de un altar de reliquias y espacio funerario, recientemente: Pérez Monzón 2017, pp. 103-141.

${ }^{63}$ Aunque la capilla funeraria de la Santísima Trinidad se sitúa en el ábside, el túmulo en las celebraciones se situaba en la Vía Sacra, donde se colocaba el Lignum Crucis (Boto 2010 , pp. 290-302; Pons 2010, pp. 245-265, esp. p. 249). Sobre la capilla de la Trinidad: Alomar 1995, pp. 211-215; Domenge 1997, pp. 127-140; Pons, Molina 2012, pp. 72-100.
} 


\section{CONCLUSIONES}

Las referencias hierosolimitanas en el espacio más ritual y ceremonial de la catedral de Toledo formaban parte del lenguaje simbólico de la sede primada de España. El cuestionado ascenso al trono de Sancho IV pudo propiciar un programa iconográfico de exaltación monárquica en su capilla funeraria que recordara su estirpe regia a través de las esculturas de reyes y antecesores enterrados en la capilla de la Santa Cruz y su poder a través de las reliquias allí depositadas en un evocador sepulcro hierosolimitano. Había culminado el proyecto de enterramiento santo en el monumento religioso más importante de la España medieval, la catedral primada de Toledo. Tras la reforma del trascoro y altar mayor a partir de finales del s. XV por los cardenales Pedro González de Mendoza y Francisco Jiménez de Cisneros, con el beneplácito de los Reyes Católicos, concluía el proyecto de Jiménez de Rada, las aspiraciones de Sancho IV y Alfonso XI, y la visión de una Jerusalén celeste en la terrenal catedral de Toledo.

\section{BIBLIOGRAFÍA CITADA}

Abad Castro, Concepción (2004), La Iglesia de san Román de Toledo, Toledo, Iberdrola.

Alomar Esteve, Gabriel (1995), La Capilla de la Trinidad y las tumbas de los reyes de Mallorca, en Pascual, Aina (coord.), La Catedral de Mallorca, Palma de Mallorca, José J. de Olañeta, pp. 211-215.

Alonso Álvarez, Raquel (2010), "Ploraverunt lapides et manaverunt aquam". El planto por el rey según las crónicas de los reinos occidentales hispánicos, en Bouquet, Damien (coord.), Politiques des émotions au Moyen Âge, Florencia, Galluzzo, pp. 115-148.

Alvar Ezquerra, Carlos; Lucía Megías, José Manuel (2002), Diccionario filológico de literatura medieval española: textos y transmisión, Madrid, Castalia.

Arciniega García, Luis (2012), La Passio Imaginis y la adaptativa militancia apologética de las imágenes en la Edad Media y Moderna a través del caso valenciano, "Ars Longa" 21, pp. 71-94.

Arias Guillén, Fernando (2015), Enterramientos regios en Castilla y León (c. 842 1504). La dispersión de los espacios funerarios y el fracaso de la memoria dinástica, "Anuario de Estudios Medievales" 45/ 2, pp. 643-675.

Arias Nevado, Javier (2006), El papel de los emblemas heráldicos en la ceremonias funerarias de la Edad Media (s.XIII-XVI), "En la España Medieval" 29/extra, pp. 49-80. 
Ayala Mallory, Nina (1969), El transparente de la Catedral de Toledo (17211732), "Archivo Español de Arte" 42/167, pp. 255-288.

Azcárate Ristori, José María de (1990), Arte Gótico en España, Madrid, Cátedra.

Ballesteros Gaibrois, Manuel (1935), El arzobispo don Rodrigo Jiménez de Rada, Madrid.

Bango Torviso, Isidro (1992), El espacio para enterramientos privilegiados en la arquitectura medieval española, "Anuario del Departamento de Historia y Teoría del Arte" 4, pp. 93-132.

Barbé, Geneviève (1992), De la Gran Mezquita a la catedral gótica, en Cardaillac, Louis; Arántegui, José Luis (coords.), Toledo, s. XII-XIII. Musulmanes, cristianos y judíos: la sabiduría y la tolerancia, Madrid, Alianza, pp. 152- 163.

Baron, Mathilde (2008), Jiménez de Rada y el episodio de la profanación de la mezquita mayor de Toledo, en Site: La Clé des Langues. Cultures et Langues Etrangères. Espagnol. Passé et Présent. L'Espagne médiévale, Lyon, Eduscol - ENS Lettres et Sciences Humaines. Mise à jour le 22/10/2008. Url: http://cle.ens-lyon.fr/espagnol/jimenez-derada-46894.kjsp [consulta: 21/06/2015].

Billot, Claudine (1987), Les Saintes Chapelles (XIII ${ }^{e}-X V I^{e}$ siècles). Approche comparée de fondations dynastiques, "Revue d'Histoire de l'Eglise en France" 73, pp. 229-248.

Billot, Claudine (1998), Les Saintes Chapelles, royales et princières, París, Patrimoine.

Boto Varela, Gerardo (2010), Panthéons Royaux des Cathédrales de SaintJacques-de-Compostelle et de Palma de Majorque. À la recherche d'un espace funéraire qui n'a jamais été utilisé, "Espace ecclésial et liturgie au Moyen Âge" 53, pp. 275-309.

Boto Varela, Gerardo (2012), Aposentos de la memoria dinástica. Mudanza y estabilidad en los panteones regios leoneses (1157-1230), "Anuario de Estudios Medievales" 42/2, pp. 535-565.

Campoy Camon, José María (1929), Documentos inéditos en la catedral de Toledo, "Boletín de la Real Academia de Bellas Artes y Ciencias Históricas de Toledo" 38-39, pp. 112-118.

Carpo, Mario (2003), La arquitectura en la era de la imprenta, Madrid, Cátedra.

Carrero Santamaría, Eduardo (2005), La sacristía catedralicia en los reinos hispanos. Evolución topográfica y tipo arquitectónico, "Liño. Revista anual de historia del arte" 11, pp. 49-75.

Carrero Santamaría, Eduardo (2009), Presbiterio y coro en la catedral de Toledo. En busca de unas circunstancias, "Hortus Artium Medievalium" 15/2, pp. 159-171. 
Carrero Santamaría, Eduardo (2010), Iglesias y capillas del Santo Sepulcro. Entre lugar común historiográfico y la norma y práctica litúrgicas, en López-Yarto Elizalde, Amelia (ed.), Arte y patrimonio de las órdenes militares de Jerusalén en España: hacia un estado de la cuestión, Madrid, CSIC, pp. 321-334.

Carrero Santamaría, Eduardo (2011a), Retrocapillas, trasltares y girolas. Liturgia, reliquias y enterramiento de prestigio en la arquitectura medieval, en Fernández González, Etelvina (coord.), Imagen del poder en la Edad Media. Estudios in Memoriam del Prof. Dr. Fernando Galván Freile, León, Universidad de León, tomo II, pp. 65-80.

Carrero Santamaría, Eduardo (2011b) Entre almuédanos y campanas. Constantes sobre la conversión de aljamas en catedrales, "Hortus Artium Medievalium" 17, pp. 185-200.

Carrero Santamaría, Eduardo (2013), El altar mayor y el altar matinal en el presbiterio de la Catedral de Santiago de Compostela. La instalación litúrgica para el culto a un apóstol, "Territorio, Sociedad y Poder" 8, pp. 19-52.

Castillo Oreja, Miguel Ángel (2001) (ed.), Las catedrales españolas en la Edad Moderna. Aproximación a un nuevo concepto del espacio sagrado, Madrid, Fundación BBVA.

Castillo Oreja, Miguel Ángel (2007), Los espacios de la monarquía en la catedral primada: la reforma de la capilla mayor y la jura de Juana de Castilla y Felipe de Borgoña, en Mínguez Cornelles, Víctor (coord.), Visiones de la monarquía hispánica, Castellón, Universitat Jaume I, pp. 229-259.

Ceccarini, Patrizio (2013), Système architectural gothique.Théologie sciences et architecture au XIII siècle à Saint-Denis. Morphogenèse et modélisation de la basilique de Saint-Denis, 2 vols., París, L'Harmattan.

Coldstream, Nicola (2002), Medieval Architecture, Oxford, Oxford University Press.

Conant, Kenneth J. (1956), The original buildings at the Holy Sepulchre in Jerusalen, "Speculum" 31, pp. 1-48.

Corbo, Virgilio C. (1981-1982), Il santo Sepulcro di Gerusalemme. Aspetti archeologici dalle origini al periodo crociato, Jerusalem, Franciscan Printing Press.

Coüasnon, Charles (1974), The Church of the Holy Sepulchre in Jerusalem, Londres, Oxford University Press.

Delgado Valero, Clara (1987), Toledo islámico: ciudad, arte e historia, Toledo, Zocodover.

Díez del Corral, Rosario (1987), Arquitectura y mecenazgo. La imagen de Toledo en el Renacimiento, Madrid, Alianza. 
Dodds, Jerrilynn D.; Menocal, Rosa María; Krasner Balbale, Abigail (2008), The Arts of Intimacy, New Haven - Londres, Yale University Press.

Domenge Mesquida, Joan (1997), L'Obra de la Seu. El procés de construcción de la catedral de Mallorca en el tres-cents, Palma de Mallorca, Govern Balear.

Domínguez, Ana (1984), El testamento de Alfonso X y la catedral de Toledo, "Reales Sitios" 82, pp. 73-75.

Español Bertran, Francesca (2001), Silla y Custodia. Ostensorio turriforme, en Bango Torviso, Isidro G. (coord.), Maravillas de la España Medieval. Tesoro Sagrado y Monarquía, Valladolid, Junta de Castilla y León, pp. 289-293.

Español Bertran, Francesca (2002), El Gòtic Català, Manresa, Angle.

Español Bertran, Francesca (2005), El escenario litúrgico de la catedral de Girona (s. XI-XIV), "Hortus Artium Medievalium" 11, pp. 213- 231.

Español Bertran, Francesca (2007), El "Córrer les armes". Un aparte caballeresco en las exequias medievales hispanas, "Anuario de Estudios Medievales" 37/2, pp. 867-905.

Español Bertran, Francesca (2013), El Milagro y su instrumento icónico. La fortuna de las imágenes sagradas en el ámbito peninsular, "Codex Aquilarenses" 29, pp. 117-134.

Estella Bertran, Eduardo (1926), El fundador de la Catedral de Toledo, Toledo.

Folda, Jaroslav (1995), The Art of the Crusaders in the Holy Land 1098-1187, Cambridge, Cambridge University Press.

Franco Mata, María Ángela (1991), Introducción. La Catedral de Toledo en la Edad Media, en Arquitecturas de Toledo: del románico al gótico, Toledo, Junta de Castilla La Mancha, pp. 409-465.

Franco Mata, María Ángela (2010), Las Capillas, en Gonzálvez Ruiz, Ramón (coord.), La Catedral Primada de Toledo: dieciocho siglos de historia, Toledo, Promecal, pp. 180-225.

Gaier, Martin (2006), Il mausoleo nel presbiterio. Patronati laici e liturgie private nelle chiese veneziane, en Staenow, Jörg (ed.), Lo Spazio e il culto. Relazioni tra edificio ecclesiale e uso litúrgico dal XV al XVI secolo, Venecia, Marsilio, pp. 153-180.

Gaite Pastor, Jesús (2001), Panteón regio. Testamento de Sancho IV, en Maravillas de la España Medieval. Tesoro Sagrado y Monarquía, Valladolid, Junta de Castilla y León.

García González, Sonsoles (2013), El panteón regio compostelano. La pérdida de la memoria, en Los lugares de la Historia, Salamanca, Hergar Ediciones Antema, pp. 973-994. 
García Mercadal, José (1952), Viajes de extranjeros por España y Portugal, vol. I, Madrid, Aguilar.

González Zymla, Herbert (2010), Consideraciones sobre la iconografía y simbolismos del retablo relicario del Monasterio de Piedra, "Anales de Historia del Arte" extra 1, pp. 229-246.

González Zymla, Herbert (2013), El altar relicario del Monasterio de Piedra, Madrid, Real Academia de la Historia.

Gonzálvez Ruiz, Ramón (1997), Hombres y Libros de Toledo, Madrid, Fundación Ramón Areces.

Gonzálvez Ruiz, Ramón (coord.) (2010), La Catedral Primada de Toledo, Toledo, Promecal.

Gonzálvez Ruiz, Ramón (2010), Las Catedrales Antiguas de Toledo, en Gonzálvez Ruiz, Ramón (coord.), La Catedral Primada de Toledo: dieciocho siglos de historia, Toledo, Promecal, pp. 148-161.

Gordon, Dillian (2002), Thirteenth- and Forteenth-Century Umbrian Double-Sided Altarpieces: Form and Function, en Italian Panel Painting of the Duecento and Trecento, Washington, National Gallery of Art, pp. 229-249.

Gorosterratzu, Javier (1925), Don Rodrigo Jiménez de Rada, gran estadista, escritor y prelado, Pamplona, Imp. y lib. de T. Besansa.

Grabar, André (1947), Martyrium. Recherches sur le culte des reliques et l'art chrétien antique, vol. I (Architecture), París, Collège de France,

Grassotti, Hilda (1973), Don Rodrigo Ximénez de Rada: gran señor y hombre de negocios en la Castilla del s. XIII, Buenos Aires, Universidad de Buenos Aires.

Gutiérrez Baños, Fernando (1997), Las empresas artísticas de Sancho IV el Bravo, Burgos, Junta de Castilla y León.

Hediger, Christine (2007) (ed.), La Sainte-Chapelle. Royaume de France et Jérusalem céleste, Turnhout, Brepols.

Hernández Sánchez, Francisco J. (1985), Los cartularios de Toledo. Catálogo monumental, Madrid, Fundación Ramón Areces.

Hernández Sánchez, Francisco J. (1992), La Catedral, instrumento de asimilación, en Cardaillac, Louis; Arántegui, José Luis (coord.), Toledo, s. XII-XIII. Musulmanes, cristianos y judios: la sabiduría y la tolerancia, Madrid, Alianza, pp. 79-93.

Hernández Sánchez, Francisco J. (2003), La hora de don Rodrigo, "Cahiers de linguistique et de civilisation medievales" 26, pp. 15-71.

Jiménez de Rada, Rodrigo (1989), Historia de los Hechos de España, Madrid, Alianza.

Krautheimer, Richard (1942), Introduction to an Iconography of Medieval Architecture, "Journal of the Courtauld and Warburg Institutes" 5, pp. 1-33. 
Kroesen, E. A. Justin (2000), The sepulchrum Domini through the Ages. Its Forms and Function, Lovaina, Peeters Punlishers (Liturgia Condena; 10).

Laguna, Teresa (2005), Dos fragmentos en busca de autor y una fecha equívoca. Alonso Martínez, pintor en Córdoba a mediados del siglo XIV, y las pinturas de la capilla de Villaviciosa, "Laboratorio de Arte" 18, pp. 73-87.

Laguna, Teresa (2012), "Una Capilla mía que dicen de Reyes". Memoria de la Capilla Real de la Catedral Mudéjar, la aljama cristianizada, de Santa María de Sevilla, en Catedral de Sevilla. Aula Hernán Ruiz. XIX Edición del AHR, Sevilla, Aula Hernán Ruiz, pp. 177-233.

Laguna, Teresa (2013), Devociones reales e imagen pública en Sevilla, "Anales de Historia del Arte" 23, núm. esp. II, pp. 127-157.

Leniaud, Jean Michel (2012), La basilique saint-Denis, París, Centre des Monuments Nationaux.

Linehan, Peter (1971), The spanish Church and the Papacy in the Thirteenth Century, Cambridge, Cambridge University Press.

Lop Otín, María José (2008), Los “espacios” de la catedral de Toledo y su funcionalidad durante la Edad Media, en Vizuete Mendoza, José Carlos; Martín Sánchez, Julio (coords.), Sacra loca toletana. Los espacios sagrados en Toledo, Cuenca, UCLM, pp. 223-262.

Marías Franco, Fernando (1986), La arquitectura del Renacimiento en Toledo (1541-1631), tomo III, Madrid, CSIC.

Marias Franco, Fernando; Pereda Espeso, Felipe (2004), Pedro Berruguete en Toledo, ¿éxito o fracaso de un pintor?, en Actas del Simposium Internacional Pedro Berruguete y su entorno, Palencia, Diputación de Palencia, pp. 151-167.

Martínez de Aguirre, Javier (2012), La Santa Cruz y el Santo Sepulcro: formas y espacios románicos, en Monumentos singulares del románico. Nuevas lecturas sobre formas y usos, Aguilar de Campoo, Fundación Santa María la Real, pp. 217-242.

Martínez de Aguirre, Javier; Gil Cornet, Leopoldo (2004), Torres del Río. Iglesia del Santo Sepulcro, Pamplona, Panorama.

Miquel Juan, Matilde (2013), Esteve Rovira y Starnina en Toledo. El arzobispo Pedro Tenorio y la consolidación del poder episcopal, en Mínguez Cornelles, Víctor (coord.) Las Artes y la Arquitectura del Poder, Castellón, Universidad de Jaime I, pp. 2.700-2.720.

Morris, Colin (2005), The sepulchre of Christ and the Medieval West, Suffolk, Oxford University Press.

Nickson, Thomas (2010), La Catedral: su historia constructiva, en Gonzálvez Ruiz, Ramón (coord.), La Catedral Primada de Toledo: dieciocho siglos de historia de la Catedral Primada de Toledo, Toledo, Promecal, pp. 142-148. 
Nickson, Thomas (2015), Toledo Cathedral. Building Histories in Medieval Castile, Filadelfia, Pennsylvania University Press.

Nieto Soria, Jose Manuel (2013), Los espacios de las ceremonias devocionales y litúrgicas de la monarquía trastámara, "Anales de Historia del Arte" extra 2, pp. 243-258.

Nogales Rincón, David (2011), Cultura visual y genealogía en la corte regia de Castilla durante la segunda mitad del s. XV, "e-Spania" 11 [en línea] DOI: 10.4000/e-spania.20362.

Nogales Rincón, David (2014), Rey, sepulcro y catedral. Patrones ideológicos y creación artística en torno al panteón regio en la corona de Castilla (1230-1516), en Hernández Ortega, María Victoria (coord.), Reyes y prelados. La creación artística en los reinos de León y Castilla (1050-1500), León, Sílex, pp. 257-282.

Orduna, Germán (1996), La elite intelectual de la escuela catedralicia de Toledo y la literatura en época de Sancho IV, en Alvar Ezquerra, Carlos (coord.), La literatura en la época de Sancho IV, Alcalá de Henares, Universidad de Alcalá de Henares, pp. 53-62.

Ortíz, Blas (1999), La Catedral de Toledo. 1549. Según el Dr. Blas Ortíz. Descripción Gráphica y Elegantísima de la S. Iglesia de Toledo, Toledo, Antonio Pareja Editor.

Ousterhout, Robert (2003), Architecture as Relic and the Construction of Sanctity: the Stones of the Holy Sepulcre, "Journal of the Society of Architectural Historians" 62/1, pp. 4-23.

Ousterhout, Robert (2006), Sacred Geographies and Holy Cities: Constantinople as Jerusalem, en Lidov, Alexei (ed.), Hietotopy: The Creation of Sacred Space in Byzantium and Medieval Russia, Moscú, Indrik, pp. 98-116.

Parro, Sixto Ramón (1978), Toledo en la mano, serie VI, Toledo, Instituto Provincial de Investigaciones y Estudios Toledanos.

Pellón Gómez-Calderrada, María (2009), El yacente Sancho IV en la catedral de Toledo: una promoción artística de tradición francesa, en Cosmen, María C.; Herráez Ortega, María Victoria; Pellón GómezCalcerrada, María (coord.), El intercambio artístico entre los reinos hispanos y las cortes europeas en la Baja Edad Media, León, Universidad de León, pp. 67-81.

Pereda, Felipe (2005), Le origini dell'architettura cubica: Alfonso de Madrigal, Nicola de Lira e la querelle Salomonista nella Spagna del Quattrocento, "Annali della Architettura" 17, pp. 21-52.

Pérez Higuera, María Teresa (1984), Paseos por Toledo del s. XIII, Madrid, Ministerio de Cultura. 
Pérez Higuera, María Teresa (1993-1994), El retablo mayor y el primer transparente de la catedral de Toledo, "Anales de Historia del Arte" 4, pp. 471-480.

Pérez Higuera, María Teresa (1998), Toledo. La Catedral, en Castilla-La Mancha. La España Gótica, Madrid, Encuentro, vol. 2, pp. 18- 107.

Pérez Higuera, María Teresa (2005), La catedral de Toledo en la época de la reina Isabel (1474-1504), El retablo mayor y su función eucarística, en Gómez Nebreda, María Luisa (comp.) Ysabel, la reina católica (Una mirada desde la catedral primada), Toledo, Catedral de Toledo, pp. 119-122, 385-391.

Pérez Monzón, Olga (2002), Iconografía y poder real en Castilla: las imágenes de Alfonso VIII, "Anuario del departamento de Historia y teoría del Arte" 14, pp. 19-41.

Pérez Monzón, Olga (2007), "Quando rey perdemos nun[u]ua bien nos fallamos". La muerte del rey en Castilla en el s. XIII, "Archivo Español de Arte" 320, pp. 379-399.

Pérez Monzón, Olga (2011), Escenografías funerarias en la Baja Edad Media, "Codex Aquilarensis" 27, pp. 213-244.

Pérez Monzón, Olga (2014), Visiones artísticas y consenso político en la Corona de Castilla. Lo funerario en la Baja Edad Media, en Nieto Soria, José Manuel; Villarroel González, Oscar (coords.), Pacto y consenso en la cultura política peninsular ( $s$. XI al XV), Madrid, Sílex, pp. 487-516.

Pérez Monzón, Olga (2017), "Bien contar [supieron] las gestas del buen rey". Memoria visual de Afonso VIII, en Poza, Marta; Olivares, Diana (eds.), Alfonso VIII y Leonor de Inglaterra: confluencias artísticas en el entorno de 1200, Madrid, Editorial Complutense, pp. 103-141.

Pick, Lucy K. (2006), Conflict and Coexistence: Archbishop Rodrigo and the Muslums and Jews of Medieval Spain, Ann Arbor, The University of Michigan Press.

Poirel, Dominique (ed.) (2001), L'Abbé Suger, le manifeste gothique de SaintDenis et la pensée victorine, Turnhout, Brepols.

Pons Cortès, Antoni (2010), La tomba de Jaume II a la Seu de Mallorca i el seu cerimonial de la festivitat del Dia dels Morts, en XXVIII Jornades d'Estudis Històrics Locals. La Ciutat de Mallorca i els segles del gòtic, Palma, Institut d'Estudis Baleàrics, pp. 245-265.

Pons Cortès, Antoni; Molina Bergas, Francisco (2012), Reformas y pervivencias medievales en la Capilla Real de la Seu de Mallorca. El caso del retablo gótico del altar mayor ( $s . X V$-XX), "Porticum. Revista d'Estudis Medievals" 3, pp. 72-100. 
Prados García, José María (1976), Las trazas del transparente y otros dibujos de Narciso Tomé para la catedral de Toledo, "Archivo Español de Arte" 49/196, pp. 387-416.

Ramírez Domínguez, Juan Antonio (1990), Evocar, reconstruir, tal vez soñar (sobre el Templo de Jerusalén en la historia de la arquitectura), "Anuario del Departamento de Historia y Teoría del Arte" 2, pp. 131-150.

Ramírez Domínguez, Juan Antonio (1991), Edificios y sueños. Estudios sobre arquitectura y utopía, Madrid, Nerea.

Revuelta Tubino, Matilde (1989), Inventario Artístico de Toledo. La Catedral Primada, tomo II-2, Madrid, Centro Nacional de Información Artística, Arqueológica y Etnológica.

Rivera Recio, Juan Francisco (1985), Los restos de Sancho IV en la catedral de Toledo, "Toletum (Segunda Época)" 16, pp. 127-133.

Rodríguez Izquierdo, Rosa (2006), María de Molina y la educación de Alfonso XI: las Semblanzas de Reyes del ms. 7415 de la Biblioteca Nacional, "Quintana" 5, pp. 219-231.

Ruiz Souza, Juan Carlos (2006), Capillas Reales funerarias catedralicias de Castilla y León: nuevas hipótesis interpretativas de las catedrales de Sevilla, Córdoba y Toledo, "Anuario del departamento de Historia y Teoría del Arte" 18, pp. 9-29.

Ruiz Souza, Juan Carlos (2009), Toledo entre Europa y al-Andalus en el s. XIII. Revolución, tradición y asimilación de las formas artísticas en la corona de Castilla, "Journal of Medieval Iberian Studies" 1/2, pp. 237-242.

Ruiz Souza, Juan Carlos (2012-2013), Alfonso X y el triunfo de la visualización del poder, "Alcanate" 8, pp. 221-259.

San Román Fernández, Francisco de Borja (1920), Inventario de la catedral de Toledo, hecho en el s. XIII, "Toletum" 7, pp. 121-125.

Seiler, Peter (2002), Duccio's Maestà: The Function of the Scenes from the Life of Christ in the Reverse of the Altarpiece: a new Hipotesis, en Italian Panel Painting of the Duecento and Trecento, Washington, National Gallery of Art.

Serra, Amadeo; Miquel, Matilde (2009), La capilla de San Martín en la Cartuja de Valldecrist: construcción, devoción y magnificencia, "Ars Longa" 18, pp. 65- 80.

Suárez Quevedo, Diego (1990), Arquitectura barroca en Toledo: s. XVII, Toledo, Caja de Toledo.

Torija Rodríguez, Enrique (2014), Las capillas funerarias reales de la catedral de Toledo. Elementos humanos y legitimadores, en Teijeira Pablos, María Dolores; Herráez Ortega, María Victoria; Cosmen, María 
(coords.), Reyes y prelados. La creación artística en los reinos de León y Castilla (1050-1500), León, Sílex, pp. 283-295.

Voelkle, William M.; Docampo Capilla, Javier; Pérez Monzón, Olga (2015), La Biblia de Cruzados, Valencia, Scriptorium.

Von Konsradsheim, Guido C. (1975), El ábside de la catedral de Toledo, "Archivo Español de Arte" 48/190-191, pp. 217-224.

Fecha de recepción del artículo: julio 2015

Fecha de aceptación y versión final: abril 2016 